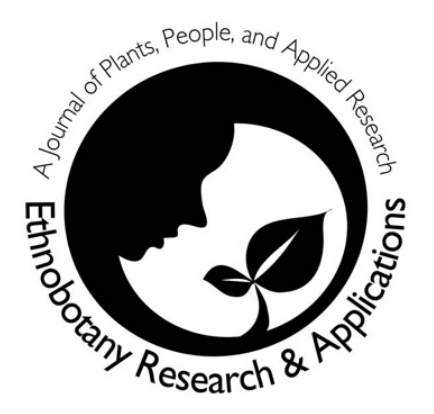

\title{
Ethnobotanical survey of medicinal plants used in the treatment of kidney stones in Region of Fez- Meknes, Morocco
}

\author{
Kenza Ammor, Fatima Mahjoubi, Dalila Bousta, Abdellah \\ Chaqroune
}

\section{Research}

\begin{abstract}
Background: This survey was carried out in the prefecture of Fez-Morocco in order to establish an inventory of medicinal plants used in the treatment of urolithiasis pathology and to collect as much information as possible about the therapeutic uses and recipes reported by the local population.
\end{abstract}

Methods: An ethnobotanical survey undertaken between January 2015 to December 2017 in the region of Fez-Meknes (Morocco) which includes the urban community of Fes-Medina, Hassan II University Hospital Center, and Sidi Hrazem which include the thermal Spring. A total of 380 individual who knew about and/or had used the medicinal plants for the indicated disease, including some herbal healers. The inventory of medicinal plants is summarized in a synoptic table, which contains the scientific, vernacular and common name of the plant, the part of the plant used, and the preparation mode is presented. The data were analysed through relative frequency of citations (RFC).

Results: After the analysis of the data collected, 54 plant species belonging to 28 families, including that of the Apiaceae (19\%), the most represented with 9 species. Similarly, the results obtained show that the majority of the medicinal plants used in the treatment of lithiasis are prepared as decoction from aerial parts. Among the most cited plants we find Herniaria hirsuta L., Zea mays L., Opuntia ficus indica L., Zizyphus lotus L, Ammi visnaga L. and Petroselinum sativum Hoffm.

Conclusion: This study showed the importance of herbal remedies for the treatment of kidney stones. The understanding use of these medicinal plants for the treatment of renal lithiasis can contribute to the identification of natural active molecules which can be useful in pharmacology.

Keywords: Kidney stones, Ethnobotanical survey, Medicinal plants, Therapeutic uses, Fez-Meknes (Morocco).

\section{Correspondence}

Kenza Ammor ${ }^{1}$, Fatima Mahjoubi ${ }^{1}$, Dalila Bousta $^{2}$, Abdellah Chaqroune ${ }^{1}$

${ }^{1}$ Laboratory of Materials Engineering and Environment, Sidi Mohammed Ben Abdelah

University, Faculty of Sciences Dhar El Mahraz, B.P 30003, Fez, Morocco.

${ }^{2}$ Laboratory of Neuroendocrinology, Nutritional and Climatic Environment, Sidi Mohammed Ben Abdelah University, Faculty of Sciences Dhar El Mahraz, B.P 30003, Fez, Morocco

${ }^{*}$ Corresponding Authors:

kenza.ammor1@gmail.com

\section{Ethnobotany Research \& Applications} 19:50 (2020)

\section{Background}

Urolithiasis is a common pathology that involves with the socio-economic and health levels of populations. It is characterized by the formation of crystalline concretion in the urinary tract, it is a known affection within the active worldwide population. It affects 4 to $20 \%$ of the general population with a recidivism rate approaching $50 \%$ (Johnson et al. 1979). It is caused by a wide variety of causes metabolic, nutritional, infectious, anatomical and / or drug-related. The 
identification of each variety requires clinical and biological investigations.

The recurrence of urolithiasis is a serious problem and, therefore, computational therapy is strongly recommended. The use of extracorporeal shock wave (ESW) lithotripsy can cause acute kidney damage, decreased renal function, hemorrhage, hypertension, and increased recurrence of stones. In addition, persistent residual stone fragments and the possibility of infection after ESW are a serious problem in the treatment of stones (Selvam et al. 2001). Thus, an alternative treatment using herbal medicine has been suggested.

In Morocco, studies carried out on urolithiasis remain few, they were interested in determining the composition of kidney stones collected in certain regions (El Kabbaj et al. 2000, Fekak et al. 2006, Laziri et al. 2010, Oussama et al 2000). These studies have shown the preponderance of calcium oxalate monohydrate as the major constituent of urinary stones.

An ethnopharmacological study has collected information on the therapeutic practices used by the population of the southern region of Morocco in the treatment of kidney stones. The medicinal plants identified during this ethnopharmacological study among the population of Tan-Tan province is divided into 29 families and 50 species used in the treatment of renal lithiasis. Among the most famous antilithiasis plants are: Herniaria hirsuta L., Zizyphus lotus L., Opuntia ficus indica L., Zea mays L. and Ammi visnaga L. (Ghourri et al. 2013). Another ethnopharmacological study was conducted on the population of Rabat, Salé and Témara (Khouchla et al. 2016). The analysis of the results, obtained from the questionnaire forms, made it possible to identify 35 plant species from 23 families. Also, the family species most cited are: Herniaria hirsuta L., Petroselium crispum Mill, Zizyphus lotus L. and Citrus limon L.

A survey carried out in the Kenitra region found that the most commonly used species against kidney stones are: Herniaria hirsute L., Glycyrrhiza glabra L., Opuntia ficus-indica L., Hordeum vulgare L. and Agropyrum repens L. (Salhi et al. 2010). A study has shown that the species Herniaria hirsute L. has a large population relative to other taxa (Hseini et al. 2010). It is effective in the therapy of kidney stones in the region of Rabat, they also found that: Zea mays L., Zizyphus lotus L., Opuntia ficus indica L., especially prescribed as a cure for diseases of the urinary tract. Also, three other species used in the region of Zaër (Western Morocco) has been identified in the treatment of urolithiasis Artemisia absinthium L., Lawsonia inermis L., Ranunculus bullatus L. (Lahsissene et al. 2009).

In this context, the ethnobotanical study undertaken aims to identify, create a database of medicinal plants used in the treatment of urolithiasic pathology and to collect all the information about the therapeutic uses practiced by the population Fez and its region.

\section{Materials and methods}

\section{Study area}

The study area is located in the prefecture of Fez, in north-east of Morocco and belonging to the region of Fez-Meknes. It's surrounded in the North by TangierTetouan-Al Hoceima region. It is limited to the west of the Rabat-Salé-Kenitra region; In the South-West, the region of Beni Mellal-Khénifra; East of the Oriental region and in the South the region of DrâaTafilalet (Figure 1).

This province covers an area of $312 \mathrm{~km}^{2}$ with a population of 977946 inhabitants of which $98 \%$ are urban, the density is 3134 inhabitants per $\mathrm{km}^{2}$.

The province is characterized by a climate ranging from Mediterranean to continental in winter and hot summer. The climate of the high zones of Rif and Pre Rif is mild in summer, while in winter it is colder with frequent and strong frosts. Continental areas are prone to 'Chergui' blows, which contribute to higher temperatures.

The province of Fez has significant natural, human and economic potentialities which, exploited in a rational and integrated way, are likely to ensure a sustained and coherent development. The province also has a diversified economy with crucial productive sectors, primarily the agricultural sector, followed by the industrial and energy sector, without forgetting the tourism sector, which will play a key role in the next years in the social and economic development of the region (Monographie Generale, 2017).

\section{Ethnobotanical survey}

This ethnobotanical survey work was carried out to gather as much information as possible on the plants used traditionally in the treatment of renal diseases especially kidney stones in the province of Fez.

The questionnaire was designed for local traditional healer, users of medicinal plants and the patients suffering from kidney stones, they were interviewed consistent with ethical rules, and they received information on the study objectives. 


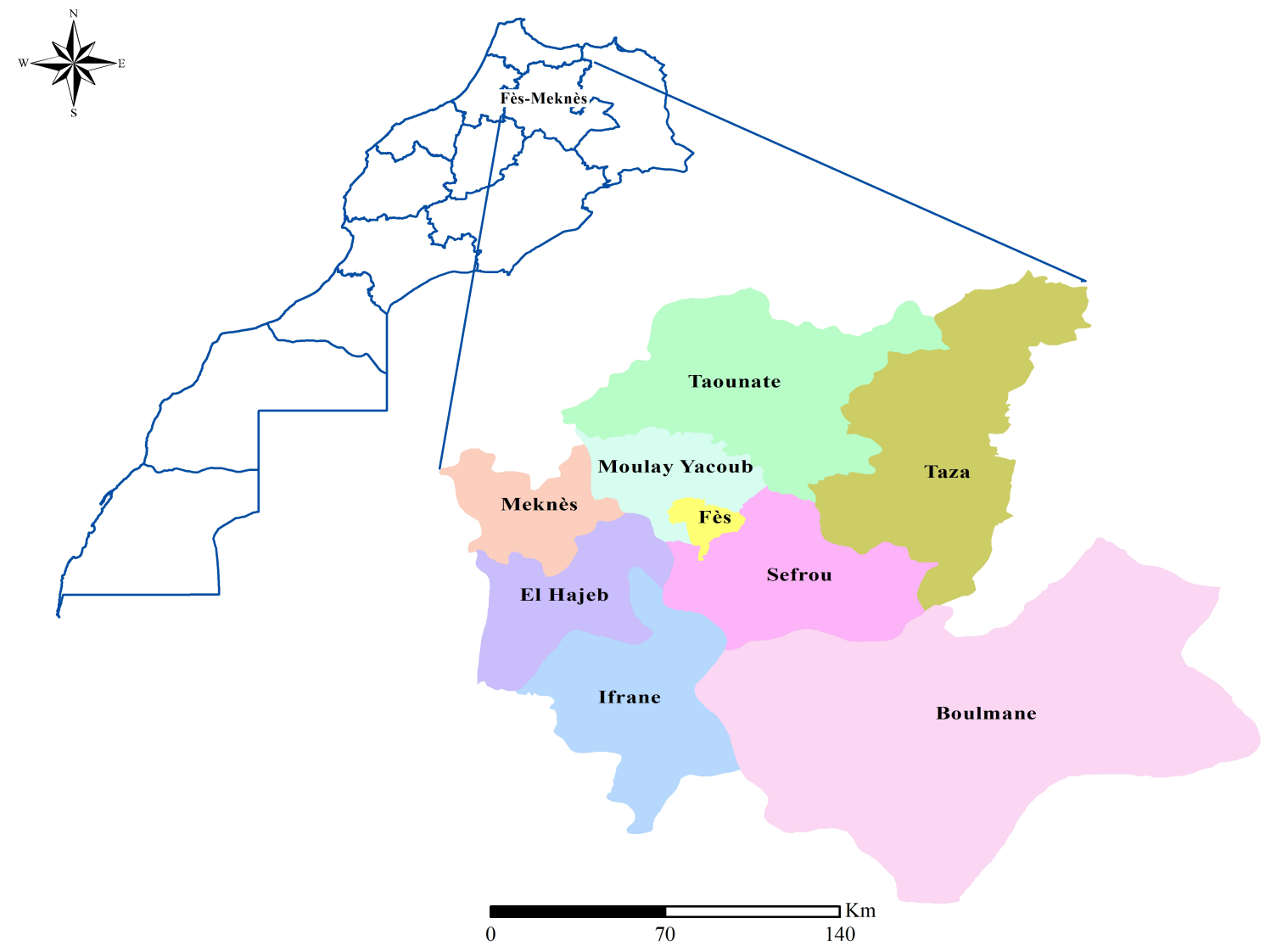

Figure 1. Map of the study area

The survey was performed in different urban communes of the prefecture of Fez: Zouagha Moulay Yacoub, Fez-Medina, Fez Jdid-Dar Dbibagh, the University Hospital Hassan II and rural commune of Sidi Hrazem. This ethnobotanical survey was performed with the permission of Public Health and local authorities.

Through a random sample of 380 people, the population was surveyed from January 2015 to December 2017. A questionnaire has been completed through face-to face interviews. The language used was the local Arabic dialect, spoken by the interviewer.

During each interview we had collected all the information about the person interviewed such as general data about the informant (name, sex, age), cultural level, professional activity, name of the plant, parts used, the precision of doses, the method of preparation and route of administration as well as treatment duration.

The freshly collected plants were dried in the shade and protected from light in a dry and ventilated place. The different species have been identified and samples were deposited at the herbarium of the laboratory of Biotechnology and Preservation of Natural Resources of the Faculty of Sciences Dhar El Mahraz. The scientific nomenclature was determined at the species level, using some documents (Bellakhdar 1978, Bellakhdar 1997,
Emberger 1938, Fennane \& Ibn Tattou 1998 Fennane et al. 1999, Fennane et al. 2007, Fennane \& Ibn Tattou 2008, Fennane \& Ibn Tattou 2012, Fennane et al. 2014, Hmamouchi 2001, Jamaleddine et al. 2017, Maire 1952- 1987, Négre 1961, Quezel \& Santa 1963, Sijelmassi 1993, Valdes et al. 2002).

Based on the information gathered, a list of the plant used in the treatment of kidney stones (or plant product) was compiled (Table 1).

\section{Statistical analysis}

Raw data entries were carried out using Microsoft Excel 2016 for windows, also, frequencies were calculated with Microsoft Excel 2016 for windows and figures were made with Microsoft Excel 2016 for windows.

\section{Relative frequency of citation (RFC)}

This index shows the local importance of each species. It is given by the frequency of citation (FC, the number of informants mentioning the use of the species) divided by the total number of informants participating in the survey $(\mathrm{N})$, without considering the use-categories (Vitalini et al. 2013).

$$
\mathrm{RFC}=\mathrm{FC} / \mathrm{N}(0<\mathrm{RFC}<1)
$$




\section{Results and discussion}

The medicinal plants identified during this ethnobotanical study among the population of Fez province are divided into 28 families and 54 species.

\section{Informant profile}

Use of medicinal plants according to gender

The use of plants varied by gender. Women $(64 \%)$ use plants more frequently than men (36\%). These results confirm the data obtained by other ethnobotanical work done nationally. They have reported that generally, women are more in possession of traditional phytotherapy knowledge (Mehdioui et al. 2007) and they used medicinal plant more than men with percentage of $(61-65 \%$ and $35-$ $39 \%)$, respectively.

The results obtained could be explained by:

$>$ Women are more connected to traditional practices.

$>$ The facility of transmission of information among women. This may explain their relative knowledge of medicinal plants uses.

$>$ Women are present at time when we have made our inquiries

$>$ women benefit more from medicinal properties to relieve the pain of their children and to maintain the health of their families (El Beghdadi 1991, Hamdani 1984, Jaouad 1992, Nabih 1992, Ziyyat et al. 1997).

Use of medicinal plants according to age

The use of medicinal plants in the studied area is widespread in all age groups (Figure 2). However, people over the age of 60 show a relatively high frequency of use of medicinal plants (24\%).
Knowledge of the properties and uses of medicinal plants is generally acquired through a long experience accumulated and transmitted from one generation to the next. The transmission of this knowledge is in danger at present because it is not always assured (Anyinam et al. 1995).

The results show that people in the 40 to 60 age group have more knowledge of medicinal plants than other age groups. The accumulated experience with age is the main source of information at the local level about the use of plants in traditional medicine.

We note that the persons under 20s have a negligible knowledge of medicinal plants (6\%), which reflects the low transmission of the traditional empirical knowledge of the elderly to the young, the mistrust particularly of young people, who tend not to believe in this traditional medicine, also in the development of medical care offers and more to trust conventional medicine.

\section{Use of medicinal plants according to level of education}

We note that the majority of users of medicinal plants in the province of Fez are illiterate with a percentage of $58 \%$. Nevertheless, people with primary school level have a significant percentage of use $(21.14 \%)$ of medicinal plants; while those with a high school and university level, use very little medicinal plants (12\% and $8.86 \%$ respectively) (Figure 3 ). Other studies have shown that the knowledge of the population on the use of medicinal plants is held by illiterate people (Benkhnigue et al. 2011, El Yahyaoui et al. 2015, Khouchlaa et al. 2016, Lahsissene et al. 2009,).

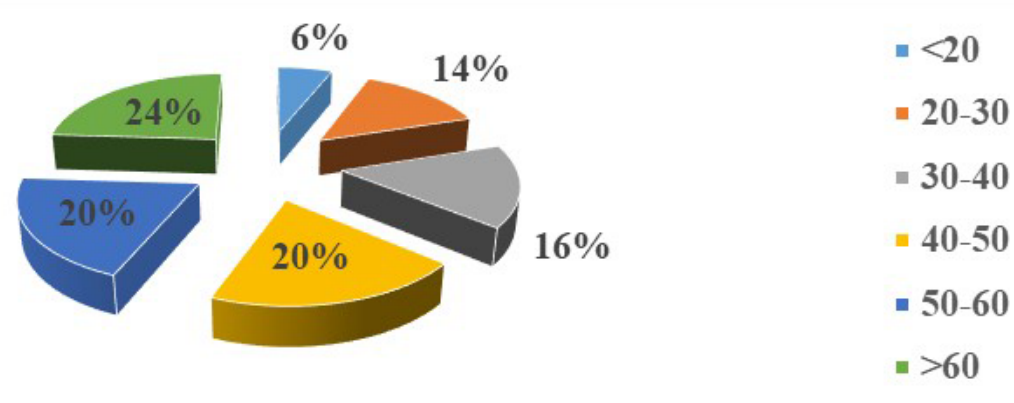

Figure 2. Frequency of use of medicinal plants according to age

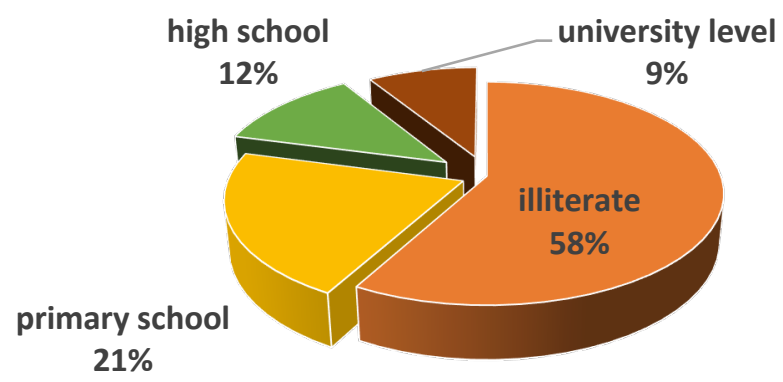

Figure 3. Frequency of use of medicinal plants according to level of literacy 
Use of medicinal plants according to family situation

The results of the survey show that medicinal plants are much more commonly used by married people $(68 \%)$ than by single people (32\%). This may be due to the couple's responsibility to their family members, thus seeking to satisfy their health care by using natural remedies, which are effective and less expensive than the material charges required by the doctor and the pharmacist.

This result is indeed obtained by others ethnopharmacological studies proving that married people use medicinal plants much more than single persons (Benkhnigue et al. 2011, El Yahyaoui et al. 2015, Khouchlaa et al. 2016, Lahsissene et al. 2009).

\section{Analysis of data according to the plants used Floristic aspects}

The floristic analysis of the survey allowed us to differentiate 54 species belonging to 28 botanical families. In addition, the ranking of families based on the number of respondents; showed the predominance of seven families in this flora: Apiaceae (9 species is $18.95 \%$ ), caryophyllaceae (1 species only is $11.84 \%$ ), Poaceae (3 species is 10 $\%$ ), lamiaceae (5 species is $8.16 \%$ ), Cactaceae (1 species is $7.11 \%$ ), Rhamnaceae ( 1 species is 6.32 $\%)$, Fabaceae (5 species is $5 \%$ ).

An ethnobotanical study on the identification of medicinal plants used in the treatment of lithiasis in the Tan-Tan region (southern Morocco), surveyed in 2007 and 2011, identified 50 species belonging to 29 families. Apiaceae are the most represented family (Ghourri et al. 2013). And also, (Khouchala et al. 2016), who carried out an ethnopharmacological survey of the plants used in the treatment of urolithiasis in Morocco, and who identified 35 species which are divided into 23 botanical families, found that the caryophylaceae are the most predominant.
Our result is in agreement with previous reports where these families were the most represented families in kidney stones treatment in Morocco (Ghourri et al. 2013; Khouchala et al. 2016). Dominance of these families could be attributed to their abundance in the Moroccan flora (Fennane and Ibn Tattou, 2012).

\section{Part used}

We obtained a total of 11 parts of plants used including: aerial part, rhizome, fruit, stigmas, flowers, entire plants, seeds, root, pericarp, leaves and bulb. The results obtained from our surveys show that the aerial parts are the most used by the population with a percentage of $(29.63 \%)$, fruits and seeds with $(20.37 \%$ each), leaves $(16.67 \%)$, the flowers $(7.41$ $\%)$, the bulbs and roots each (5.56\%), whole plant and pericarp each $(3.70 \%)$, and finally the rhizome and the stigmas each (1.85\%) (Figure 4).

The high frequency of use of aerial parts can be explained by the fact that they are the site of photosynthesis and sometimes the storage of secondary metabolites responsible for the biological properties of the plant (Bigendako \& Lejoly1990).

\section{Mode of preparation}

In order to facilitate the administration of the drug, several methods of preparation are used namely decoction, infusion, maceration, poultice, powdered or raw.

The decoction is the most used method of preparation with $(81.48 \%)$, the infusion $(33.33 \%)$, the raw plant $(7.41 \%)$, the maceration, the poultice and the powdered plant each has a percentage of $1.85 \%$ (Figure 5). The use of the decoction shows that the population has confidence in this type of preparation and finds it suitable for warming the body and disinfecting the plant, also the decoction makes it possible to collect the most active ingredients attenuates or cancels the toxic effect of certain recipes (Jouad et al. 2001).

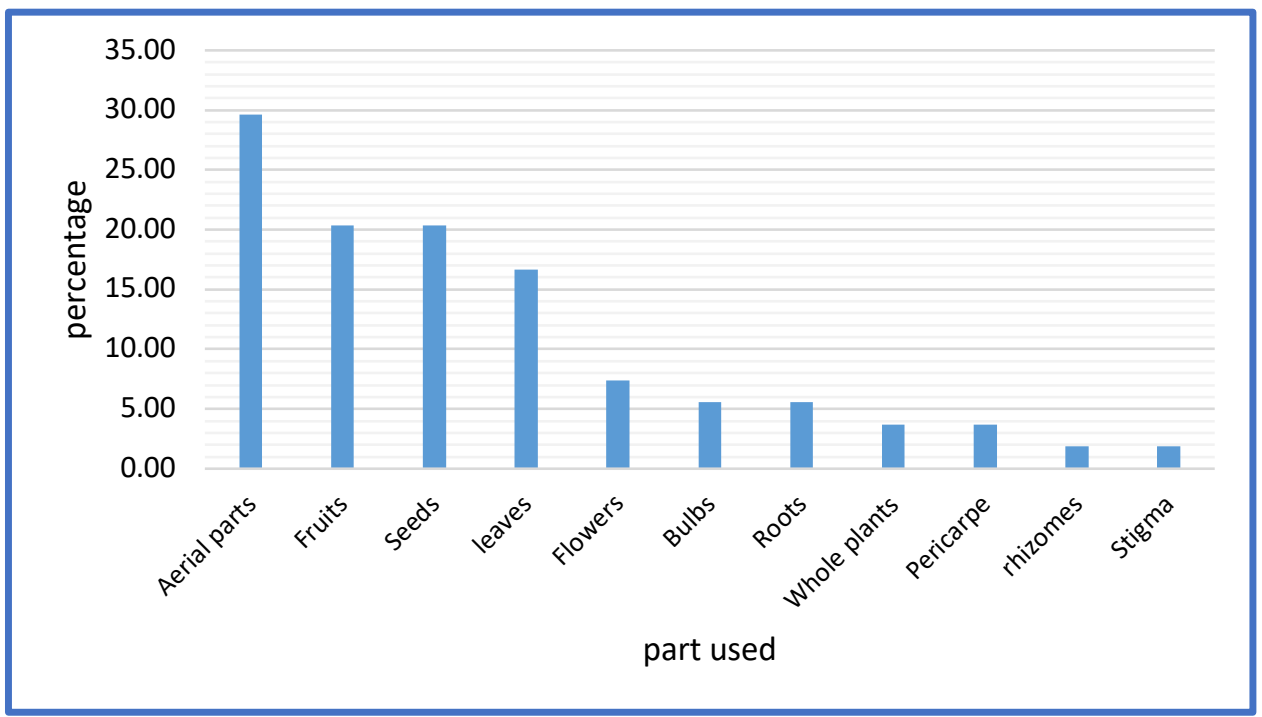

Figure 4. Percentage of different parts used 


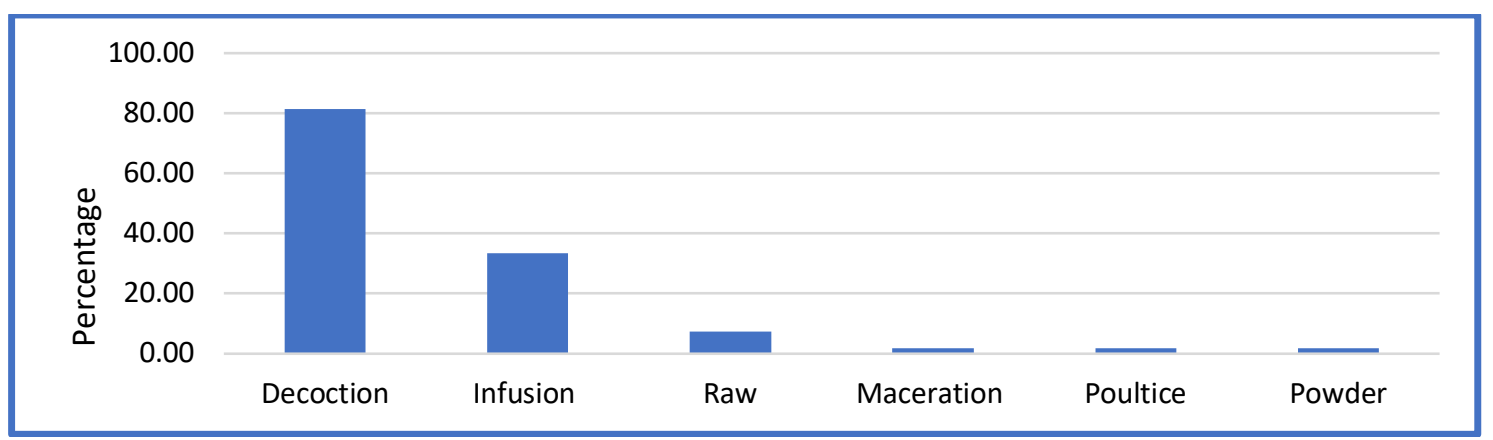

Figure 5:.Repartition of different modes of preparation

\begin{abstract}
Medicinal plants most commonly used in the treatment of kidney stones

The analysis of the data collected in the ethnopharmacological survey allowed us to identify the medicinal plants most traditionally used for the treatment of renal lithiasis. The results show that the most used plant is Herniaria hirsuta L. with (11.84 $\%$ ), followed in descending order by Zea mays L. (7.89\%), Opuntia ficus indica L. (7.11\%), Zizyphus lotus L. (6.32\%), Ammi visnaga L. (4.74\%) and Petroselinum sativum Hoff. (4.21\%).
\end{abstract}

Indeed, these results have been confirmed by similar studies carried out in other regions of Morocco (Ghourri et al. 2013, Hseini et al. 2007, Khouchlaa et al. 2016, Lahsissene et al. 2009, Salhi et al. 2010).

\section{Conclusions}

This survey demonstrates that people in the province of Fez still use medicinal plants in the treatment of diseases, especially kidney stones. It showed that kidney stones are a common pathology among the population of this province. It is related to changes in nutritional habits, sanitary conditions, environmental factors or the prevalence of pathologies that predispose to the risk of lithiasis.

The number of plants species used is very important, it is quite important to document and highlight this cultural heritage which provides the therapeutic option, be it called an alternative medicine. Furthermore, special attention should be given to the promising plants in the sector and protect them from extinction by excessive and anarchic exploitation.

It is importnat to extend this kind of ethnopharmacological survey in various regions of Morocco, in order to safeguard this know-how on the use of medicinal plants in the treatment of lithiasis and to valorize them through biochemical and pharmacological research, to determine the active substances and their proper use in the treatment of renal lithiasis.

\section{Declarations}

List of Abbreviations: RFC: Relative frequency of citations; AP: Aerial part; FR: Fruits; RZ: Rhizome; ST: Stigmata; FL: Flower; EN: Whole plant; SD: Seeds; RO: Root; PE: Pericarp; LE: Leaves; B: Bulb. D: Decoction; IN: Infusion; M: Maceration; PL: Poultice; R: Raw, PW: Powder
Ethics approval and consent to participate: Before conducting interviews, prior informed consent was obtained from all participants.

Consent for publication: Not applicable

Conflict of interest: The authors declare that they have no conflict of interest.

Financing: This manuscript did not have any funding from any organisation.

Author contributions: Kenza Ammor: Conceptualization, investigation, Writing - Original Draft. Fatima Mahjoubi: Review, Editing Conceptualization, Methodology and supervision. Dalila. Bousta: Review, Editing Conceptualization, Methodology and supervision, Abdellah Chaqroune: Review, Editing Conceptualization, Methodology and supervision.

\section{Literature Cited}

Anyinam C. 1995. Ecology and ethnomedicine: exploring links between current environmental crisis and indigenous medical practices. Social Science and Medicine 4:321-329.

Bellakhdar J. 1978. Médecine traditionnelle et toxicologie ouest-sahariennes. Ed Techniques Nord-africaines Rabat 365p.

Bellakhdar J. 1997. La pharmacopée marocaine traditionnelle. Médecine arabe ancienne et savoirs populaires. Ed Le Fennec, Paris, Ibis Press 764p.

Benkhnigue O, Zidane L, Fadli M. 2011. Étude ethnobotanique des plantes médicinales dans la région de Mechraâ Bel Ksiri (région du Gharb du Maroc). Acta Botanica Barcinonensia 53:191-216.

Bigendako-Polygenis M.J, Lejoly J. 1990. La pharmacopée traditionnelle au Burundi. Pesticides et médicaments en santé animale. Pres. Univ. Namur. Pp 425-442.

El Beghdadi, M. 1991. Pharmacopée traditionnelle du Maroc. Les plantes médicinales et les affections du système cardio-vasculaire. Thèse de Pharmacie. Faculté de Médecine et de Pharmacie Rabat.

El Kabbaj S, Meiouet F, El Amrani A. 2000. Analyse des calculs urinaires par spectrophotométrie infrarouge à propos de 218 cas au Maroc. Biol Sante 1:14-23.

El Yahyaoui O, Ait ouaaziz N, Sammama A. 2015. Étude ethnobotanique : plantes médicinales commercialisées à la province de Laâyoune : identification et utilisation. International Journal of Innovation and Applied Studies 12:533-541. 
Emberger L. 1938. Aperçu général sur la végétation du Maroc. Ed Hans Huber, Berne, Montpellier 157p.

Fekak H, Sahnoun A, Rabii R. 2006. La lithiase urinaire : étude spectrophotométrie infrarouge (à propos de 80 cas). Jounal Marocain d'Urologie 1:1720.

Fennane M, Ibn Tattou M. 1998. Catalogue des plantes vasculaires rares, menacées ou endémiques du Maroc. Bocconea Palerme 8:1-243.

Fennane M, Ibn Tattou M, Mathez J. 1999. Flore pratique du Maroc, Vol 1. Institut Scientifique Ibn battouta 36:558.

Fennane M, Ibn Tattou M, Ouyahya A, El Oualidi J. 2007. Flore pratique du Maroc, Vol 2. Institut Scientifique Ibn battouta 38:636.

Fennane M, Ibn Tattou M. 2008. Inventaire et chorologie des plantes vasculaires du Maroc. Institut Scientifique Ibn battouta 37 (483 p), 39 (398 p).

Fennane M, Ibn Tattou M. 2012. Statistiques et commentaires sur l'inventaire actuel de la flore vasculaire du Maroc. Bulletin de l'institut Scientifique Rabat, section Sciences de la Vie 34:1-9.

Fennane M, Ibn Tattou M, El Oualidi J. 2014. Flore pratique du Maroc, Vol 3. Institut Scientifique Ibn battouta 40:793.

Ghourri M, Zidane L, Dourira A. 2013. Usage des plantes médicinales dans le traitement lithiase rénale dans la province de Tan- Tan (Maroc saharien). International Journal of Chemical Sciences 7:1688-1700.

Hamdani S.E. 1984. Médecine traditionnelle à Boujaad. Thèse de Pharmacie. Faculté de Médecine et de Pharmacie Rabat.

Hmamouchi M. 2001. Les plantes médicinales et aromatiques marocaines. 2éme. Ed 389p.

Hseini S, Kahouadji A. 2007. Étude ethnobotanique de la flore médicinale dans la région de Rabat (Maroc occidental). Lazaroa 28:79-93.

Jamaleddine M, El Oualidi J, Taleb M.S, Thévenin T, El Alaoui-Faris F.E. 2017. Inventaire et état de conservation des plantes aromatiques et médicinales (PAM) au Maroc. Ethnopharmacologie $1: 1-9$.

Jaouad L. 1992. Enquête ethnobotanique : la part de la médecine traditionnelle dans les différentes couches socio-économiques de la population de Casablanca. Thèse de Pharmacie. Faculté de Médecine et de Pharmcie Rabat.

Johnson CM, Wilson DM, O'fallon WM, Malek RS, Kurland LT. 1979. Renal stone epidemiology: a 25year study in Rochester, Minnesota. Kidney International 16:624.

Jouad H, Haloui M, Rhiouani H, El Hilaly J, Eddouks M. 2001. Ethnobotanical survey of medicinal plants used for the treatment of diabetes, cardiac and renal diseases in the North centre region of Morocco (FezBoulemane). Journal of Ethnopharmacology 77:175-82.

Khouchlaa, A, Tijane M, Chebat A, Kahouadji A. 2017. Enquête ethnopharmacologique des plantes utilisées dans le traitement de la lithiase urinaire au Maroc. Phytothérapie 15:274-287.
Lahsissene $\mathrm{H}$, Kahouadji A, Tijane $\mathrm{M}$ et Hseini S. 2009. Catalogue des plantes médicinales utilisées dans la région de Zaër (Maroc occidental). Lejeunia 186.

Laziri F, Rhazi Filali F, Oussama A, Soulaymani A, Qarro A, Lezrek M. 2010. Facteurs impliqués dans l'épidémiologie des calculs urinaires marocains. Journal Marocain d'Urologie 19:9-14.

Maire R. 1987. Flore de l'Afrique du nord, vol 1-16.

Mehdioui, R, Kahouadji A. 2007. Etude ethnobotanique auprès de la population riveraine de la forêt d'Amsittène: cas de la Commune d'Imi n'Tlit (Province d'Essaouira). Bulletin de l'Institut Scientifique, Rabat, section Sciences de la Vie 29:11-20.

Monographie Generale. 2017. ROYAUME DU MAROC Ministère de I'Intérieur Direction Générale des Collectivités Locales, haut-commissariat du plan.

Nabih M. 1992. Secrets et vertus thérapeutiques des plantes médicinales utilisées en médecine traditionnelle dans la province de Settat. Thèse de Pharmacie. Faculté de Médecine et de Pharmacie Rabat

Négre R. 1961. Petite flore des régions arides du Maroc occidental, tome 1, Paris.

Oussama A, Kzaiber F, Mernari B, Hilmi A, Daudon M. 2000. Analyse des calculs urinaires de l'adulte dans le Moyen Atlas marocain par spectrophotométrie infrarouge à transformée de Fourier. Progrès en Urologie 10:404-410.

Quezel, P, Santa S. 1963. Nouvelle Flore d'Algérie et des Régions Désertiques Méridionales. 2 Tomes, Editions CNRS, Paris 1170.

Salhi S, Fadli M, Zidane L, Douira A. 2010. Etudes floristique et ethnobotanique des plantes médicinales de la ville de Kénitra (Maroc). Lazaroa 31:133-46.

Selvam P, Kalaiselvie P, Govindaraj A, Murugan VB, Sathishkumar AS. 2001. Effect of $A$. lata leaf extract and vediuppu on the urinary risqué factors of calcium oxalate urolithiasis during experimental hyperxaluria. Pharmacological Research 43:89-93.

Sijelmassi A. 1993. Les plantes médicinales du Maroc, 6ème édition. Le Fennec, Casablanca. 285p. Valdes B, Rejdali M, Achhal A, Jury JL, Montserrat JM. 2002. Catalogue des plantes vasculaires du Nord du Maroc, vol. 1 \& 2. CSIC, Madrid.

Vitalini S, Iriti M, Puricelli C, Ciuchi D, Segale A, Fico G. 2013. Traditional knowledge on medicinal and food plants used in Val San Giacomo (Sondrio, Italy)-An alpine ethnobotanical study. Journal of Ethnopharmacology 145:517-529.

Ziyyat, A, Legssyer A, Mekhfi H, Dassouli A, Serhrouchni M, Benjelloun W, 1997. Phytotherapy of hypertension and diabetes in oriental Morocco. Journal of Ethnopharmacology 58:45-54. 
Table 1 Medicinal plants used for the treatment of kidney stones in the region of Fez-Meknes Morocco

\begin{tabular}{|c|c|c|c|c|c|c|}
\hline Family & Scientific name & $\begin{array}{c}\text { Voucher specimen } \\
\text { number }\end{array}$ & $\begin{array}{l}\text { Vernacular } \\
\text { name }\end{array}$ & Part used & $\begin{array}{l}\text { Mode } \\
\text { of use }\end{array}$ & $\%$ RFC \\
\hline Aloeaceae & Aloe barbadensis L. & RAB064442 & Sabra/ sebar & AP & $\mathrm{R}$ & 0.79 \\
\hline Anacardiaceae & Pistacia atlantica Desf. & RAB38238 & Betma & AP & $\mathrm{D}$ & 1.05 \\
\hline \multirow[t]{9}{*}{ Apiaceae } & Ammi visnaga $\mathrm{L}$. & RAB76986 & Bechnikha & FR & $\mathrm{D}$ & 4.74 \\
\hline & Ammodaucus leucotrichus Coss. \& Durieu & RAB62313 & Kamoun soufi & SD & $\mathrm{D}$ & 1.05 \\
\hline & Apium graveolens $\mathrm{L}$. & RAB38370 & كرفس / Krafes & AP & DIN & 1.84 \\
\hline & Carum carvi L. & RAB39451 & Karwia & FR & $\mathrm{D} / \mathrm{IN}$ & 1.05 \\
\hline & Coriandrum sativum $\mathrm{L}$. & RAB76745 & Qezbor & FR/AP & IN/PW & 1.84 \\
\hline & Daucus carota L. & RAB296469 & Khizo & FR/SD & $\mathrm{D}$ & 1.32 \\
\hline & Foeniculum vulgare Mill. & RAB309676 & Nafaa/besbas & SD & IN & 2.11 \\
\hline & Petroselinum sativum Schübler. \& Martens & RAB40104 & Maadnous & LE/AP & $\mathrm{D} / \mathrm{IN}$ & 4.21 \\
\hline & Pimpinella anisum $\mathrm{L}$. & RAB1255256 & Habaat hlawa & FR & $\mathrm{D} / \mathrm{IN}$ & 0.79 \\
\hline Apocynaceae & Caralluma europaea Guss. & RAB005358 & Daghmous & AP & $\mathrm{R}$ & 0.79 \\
\hline \multirow[t]{2}{*}{ Asteraceae } & Anthemis nobilis L. & RAB4117421 & Babounj & AP/ FL/LE & $\mathrm{D}$ & 0.79 \\
\hline & Artemisia herba-alba Asso. & RAB331471 & Chih & SD & $\mathrm{D}$ & 0.79 \\
\hline \multirow[t]{2}{*}{ Brassicaceae } & Lepidium sativum $\mathrm{L}$. & RAB622089 & Hebb rchad & SD & $\mathrm{D} / \mathrm{IN}$ & 0.79 \\
\hline & Raphanus sativus L. & RAB635844 & Fjel & SD & $\mathrm{D}$ & 1.58 \\
\hline Cactaceae & Opuntia ficus-indica L. & RAB1264407 & Hendi & $\mathrm{FL}$ & $\mathrm{D} / \mathrm{IN}$ & 7.11 \\
\hline Capparidaceae & Capparis spinosa L. & RAB125618 & Kbar & FR & $\mathrm{D}$ & 1.32 \\
\hline Caryophyllaceae & Herniaria hirsuta L. & RAB090814 & Herras Ihejr & AP & $\mathrm{D} / \mathrm{IN}$ & 11.84 \\
\hline Euphorbiaceae & Euphorbia falcata L. & RAB077696 & Hayat nufus & EN & $\mathrm{D} / \mathrm{IN}$ & 1.32 \\
\hline \multirow[t]{5}{*}{ Fabaceae } & Ceratonia siliqua L. & RAB93948 & Kharub & FR & $\mathrm{D}$ & 0.79 \\
\hline & Glycyrrhiza glabra L. & RAB07693 & Araq sus & RO & $\mathrm{D}$ & 1.58 \\
\hline & Medicago sativa L. & RAB111097 & Fessa & SD & $\mathrm{D}$ & 0.79 \\
\hline & Ononis natrix L. & RAB091293 & Henet reg & AP & $\mathrm{D}$ & 0.79 \\
\hline & Trigonella foenum-graecum L. & RAB152969 & Helba & SD & $\mathrm{M}$ & 1.05 \\
\hline Iridaceae & Crocus sativus L. & RAB151373 & Zaafran Ihor & ST & $\mathrm{D}$ & 1.32 \\
\hline Juncaceae & Juncus acutus L. & RAB052678 & Smar & SD & $\mathrm{D}$ & 1.58 \\
\hline \multirow[t]{5}{*}{ Lamiaceae } & Marrubium vulgare L. & RAB476943 & Merriwa & $\mathrm{AP}$ & $\mathrm{D}$ & 1.32 \\
\hline & Lavandula dentata L. & RAB191686 & Khzama bldiya & AP & $\mathrm{D}$ & 1.05 \\
\hline & Lavandula multifida L. & RAB448543 & Khila & AP & $\mathrm{D}$ & 1.32 \\
\hline & Origanum compactum Benth. & RAB250616 & Zaater & LE & $\mathrm{D} / \mathrm{IN}$ & 1.84 \\
\hline & Rosmarinus officinalis L. & RAB180597 & Azir & LE & $\mathrm{D}$ & 2.63 \\
\hline
\end{tabular}


Ethnobotany Research and Applications

\begin{tabular}{|c|c|c|c|c|c|c|}
\hline Lauraceae & Cinnamomum verum J. Presl, & RAB2011675 & Querfa & $\mathrm{PE}$ & $\mathrm{D}$ & 0.79 \\
\hline \multirow[t]{3}{*}{ Liliaceae } & Allium cepa L. & RAB464589 & Besla & $\mathrm{B}$ & $\mathrm{D}$ & 2.11 \\
\hline & Allium porrum $\mathrm{L}$. & RAB464577 & Korat/borro & $\mathrm{EN} / \mathrm{B}$ & $\mathrm{D}$ & 0.79 \\
\hline & Allium sativum $\mathrm{L}$. & RAB464570 & Touma & $\mathrm{B}$ & $\mathrm{D}$ & 1.58 \\
\hline Linaceae & Linum usitatissimum L. & RAB111298 & Zeriat Iketan & $\mathrm{FL}$ & D & 0.79 \\
\hline \multirow[t]{2}{*}{ Myrtaceae } & Eucalyptus globulus Labill. & RAB1180934 & Eukaliptus & LE & $\mathrm{D}$ & 1.58 \\
\hline & Syzygium aromaticum (L.) Merr. \& L. M. Perry & RAB232972 & Qronfel & SD & $\mathrm{D}$ & 0.79 \\
\hline Papaveraceae & Papaver rhoeas L. & RAB398937 & Belaaman & FL/LE & D/IN/PL & 1.32 \\
\hline \multirow[t]{3}{*}{ Poaceae } & Agropyrum repens $\mathrm{L}$. & RAB236362 & Njem & RZ/AP & $\mathrm{D}$ & 2.11 \\
\hline & Cynodon dactylon L. & RAB2249455 & & & & 0.00 \\
\hline & Zea mays L. & RAB1108434 & Dra & ST & $\mathrm{IN} /$ & 7.89 \\
\hline Punicaceae & Punica granatum L. & RAB1271332 & Reman & $\mathrm{PE}$ & IN & 1.58 \\
\hline Raninculaceae & Nigella sativa L. & RAB547275 & Sanouj & SD & $\mathrm{D} / \mathrm{IN}$ & 1.05 \\
\hline Rhamnaceae & Zizyphus lotus L. & RAB357564 & Nbeg & FR/LE & $\mathrm{D}$ & 6.32 \\
\hline \multirow[t]{3}{*}{ Rosaceae } & Fragaria vesca L. & RAB508768 & Frése Iberi & FR & $\mathrm{R}$ & 0.79 \\
\hline & Prunus cerasus L. & RAB1209802 & Heb Imlouk & FR & $\mathrm{R}$ & 0.79 \\
\hline & Rubus fruticosus L. & RAB1192748 & Tut & LE/FR/RO & $\mathrm{D}$ & 0.79 \\
\hline Rubiaceae & Rubia tinctorum L. & RAB1108650 & Fowa & $\mathrm{RO}$ & D & 0.79 \\
\hline Theaceae & Camellia sinensis L. & RAB4511659 & Atay & LE & $\mathrm{D}$ & 0.79 \\
\hline Thymeleaceae & Thymelaea lythroides Barratte \& Murb. & RAB262158 & Metnan & $\mathrm{AP}$ & $\mathrm{D} / \mathrm{IN}$ & 1.05 \\
\hline \multirow[t]{2}{*}{ Urticaceae } & Parietaria officinalis L. & RAB320763 & Hriga melsa & $\mathrm{AP}$ & IN/D & 1.58 \\
\hline & Urtica urens L. & RAB671735 & Hriga hercha & $\mathrm{AP}$ & IN/D & 1.58 \\
\hline
\end{tabular}

Part used: AP: Aerial part; FR: Fruits; RZ: Rhizome; ST: Stigmata FL: Flower; EN: Whole plant; SD: Seeds; RO: Root; PE: Pericarp; LE: Leaves; B: Bulb. Mode of use: D: Decoction; IN: Infusion; M: Maceration; PL: Poultice; R: Raw, PW: Powder 


\section{Appendix - Ethnobotanical questionnaire}

\section{Fiche $n^{\circ}$ :}

Classement (par thème, ordre alphabétique, région ou autre) :

Documents annexées (photos, diapositives, herbiers...) :

\section{1-RENSEIGNEMENT SUR L'INFORMATEUR}

- Sexe : Femme. .Homme

-Age : 18-24 $\square$ 25-34 $\square$ 35-49 $\square$ 49-65 $\square 65 \geq \square$

- Origine ethnique :

- Commune:.

- Niveau d'instruction : Néant $\square$ Primaire $\square$ Secondaire $\square$ Universitaire $\square$

- Situation familiale : Célibataire $\square$ Marié $\square$

- Métier : Herboriste ..................Guérisseur ... Autres.

- Comment vous avez eu ces connaissances ? Lui-même $\square$ Expérience des autres $\square$ Herboriste $\square$

Livres $\square$ Occasionnellement $\square$ Autres $\square$

- Exerce t-il d'autre pratique médicinale traditionnelle ? Si oui, les

quels?

- Que préférez-vous ? les soins médicaux $\square$ Les soins phytothérapeutiques $\square$

-Pourquoi?.

-Qui consultez-vous en cas de maladie ? : Personnel médical $\square$ Guérisseur $\square$

-Autres :

\section{2- RENSEIGNEMENT SUR LE PRATICIEN}

Nom :. Prénom Age :

Lieu de Naissance : ou origine régionale: Lieu d'établissement : Appartenance ethnique Niveau d'instruction :

Depuis quand exerce t'il le métier de guérisseur?

Qui l'a formé.

S'il s'agit d'un praticien lettré, quels livres de médecine arabe possède-t-il ? Est 'il polyvalent ou exerce une spécialité ?.

Est -il spécialisé dans le traitement d'une maladie ?

A-t-il formé quelqu'un?.

\section{2 - RENSEIGNEMENT SUR LE PRODUIT}

\section{2-1 Simple :}

2.1.1 - Caractéristiques de l'habitat de la plante

Sol :

Relief :

Climat :

Action anthropique :

Aire de répartition : 
2.2 - Systématique

-Famille:

-Genre:

-Espèce:

2.3 Dénominations locales :

2-1 Plante : (Seule)

Parties utilisées : Tige $\square$ Fleurs $\square$ Fruits $\square$ Graine $\square$ Écorce $\square$ Rhizome $\square$ Bulbe $\square$ Latex $\square$

Feuilles $\square$ Plante entière $\square$ Autres combinaisons $\square$ :

État de la plante : Fraîche $\square$ Desséché $\square$

Forme d'emploi : Tisane $\square$ Poudre $\square$ Huiles essentielles $\square$

Lieu de récolte $: \ldots \ldots \ldots \ldots \ldots \ldots \ldots \ldots \ldots \ldots \ldots$ Lieu d'acquisition:

Produit : local $\square$ sauvage $\square$ local $\square$ cultivé $\square$ importé $\square$

Autres:

Conditions et modalités de la récolte : (saison, période du jour, etc).

Autres utilisations médicinales :

\section{2-2 Mixte : (recette)}

Parties utilisées : Tige $\square$ Fleurs $\square$ Fruits $\square$ Graine $\square$ Écorce $\square$ Rhizome $\square$ Bulbe $\square$ Feuilles $\square$

Plante entière $\square \quad$ Autres combinaisons $\square$ :

État de la plante : Fraîche $\square$ Desséché $\square$

Lieu de récolte des plantes

Lieu d'acquisition

Produit: local $\square$ sauvage $\square$ local cultivé $\square \quad$ importé $\square$

Autres

Conditions et modalités de la récolte : (saison, période du jour, etc).....

Traitement reçu par le produit : (séchage, pulvérisation)

Indications (si celles-ci varient en fonction des parties, faire une fiche pour chaque partie).

Autres utilisations médicinales :

Toxicité, effets secondaires : toxicité pour l'homme et/ou le bétail, risque et effets indésirables

$\cdots$

Dose :

Mode de préparation :

Autres $\square$ : 


\section{Posologie :}

Pour les nourrissons : 1 fois/jour $\square$ 2fois/jour $\square$ 3fois/jour $\square$ Autres $\square$ :

Pour les enfants : 1 fois/jour $\square 2$ fois/jour $\square$ 3fois/jour $\square$ Autres $\square$ :

Pour les Adultes : 1 fois/jour $\square$ 2fois/jour $\square$ 3fois/jour $\square$ Autres $\square$ :

Pour les personnes âgées : 1fois/jour $\square$ 2fois/jour $\square$ 3fois/jour $\square$ Autres $\square$ :

Durée d'utilisation (durée de traitement) :

Un jour $\square$ Une semaine $\square$ Un mois $\square$ Jusqu'à la guérison $\square$

Mode d'administration :

Utilisation Comme :

$\square$ Complément au médicament

\section{$\square$ Alternative}

Associations :

.............

Autres informations : 